\title{
UNDER CLIMATIC CHANGE, SOIL MICROBIAL COMMUNITY AND VARIABLES RELATING TO N-CYCLE ARE MODULATED BY CHANGES IN THE UPPER LIMIT TEMPERATURE
}

\author{
N. MONOKROUSOS * \\ E.M. PAPATHEODOROU \\ G.P. STAMOU
}

Department of Ecology, School of Biology, Aristotle University of Thessaloniki, UPB 119, 54006 Thessaloniki, Greece

*to whom all correspondence should be addressed: e-mail: nmonokro@bio.auth.gr

\section{ABSTRACT}

The effect of temperature increase and more specifically its upper and low level correlates on soil microbial biomass, activity and $\mathrm{N}$-cycle variables was studied in a Mediterranean shrubland. Experimental manipulation succeeded in establishing three treatments which, in comparison with the monthly ambient temperature, displayed an increase in mean monthly temperature by $2.1,4.9$ and $7.4{ }^{\circ} \mathrm{C}$ respectively. Also the upper limit temperature values $\left(T_{\max }\right)$, but not the low limit counterparts $\left(T_{\min }\right)$, differed significantly among the three treatments. $T_{\max }$ changes seemed to affect directly only the microbial biomass, while it exerted an indirect effect on the majority of the other soil variables. With increased $T_{\max }$ the values of the estimated soil microbial variables (microbial biomass and activity) increased, while other soil chemical variables, such as the inorganic forms of $\mathrm{N}$, were found reducing. Organic $\mathrm{N}$ was the only variable remaining independent from changing $\mathrm{T}_{\max }$ at any treatment. The results of this paper indicate that the level of $T_{\max }$ increase could be crucial for the structure of the microbial community. A $\mathrm{T}_{\max }$ increase up to $7^{\circ} \mathrm{C}$ induced by climate change could favour the dominance of the soil bacterial populations, while larger increases could be in favour of the fungal populations.

KEYWORDS: soil microbial biomass and activity, climate change scenarios, nitrates, ammonium, Se-path analysis, temperature increase, Mediterranean shrubland.

\section{INTRODUCTION}

The Intergovernmental Panel on Climate Change has estimated that the global mean surface temperatures have increased by $0.6{ }^{\circ} \mathrm{C}$ over the last century and with forecasted anthropogenic increases in the emission of greenhouses gases, global temperatures are predicted to rise between 1.4 and $5.8{ }^{\circ} \mathrm{C}$ in the next $50-100$ years (IPCC, 1996). Climatic changes are likely to affect ecosystem functioning (Shaver et al, 2000). Although direct and indirect effects of this potential temperature increase on terrestrial ecosystems are expected complex and highly varying in time and space, it is generally suggested that global warming can directly influence $C$ processes by changing plant photosynthesis and growth (Shaw et al., 2002) as well as soil respiration (Shaver et al., 2000). In this regard, numerous warming studies have been initiated over the past decade to examine the ecosystem-scale effects of rising temperature (Rustad et al., 2001). Particularly, changes in soil temperature regimes resulting from climate warming are expected to alter soil properties and processes, such as microbial activity, organic matter decomposition and nutrient cycling (Luo et al., 2001). For instance, increased rates of $N$ mineralization driven by climate warming may increase plant $\mathrm{N}$ availability, which, coupled with an extended growing season, could stimulate plant growth in $\mathrm{N}$-limited systems, provided water is not limited (Sierra, 1997; De Valpine and Harte, 2001).

Relevant studies indicate that air temperature in Mediterranean basin has already shown warming trends (Kutiel and Maheras, 1998; Penuelas et al., 2005; Penuelas and Boada, 2003) and with respect to the argument we are proposed to develop herewith it is noticeable that Mediterranean 
ecosystems are considered vulnerable to multiple environmental pressures such as those induced by climate change (Dimitrakopoulos et al., 2005; Fyllas and Troumbis, 2009). Among them, Mediterranean shrubland ecosystems are often natural or seminatural and cover relatively large areas around Mediterranean Sea. In their majority these are dominated by evergreen shrubs and characterized by long lasting turnover of nutrients in plants and soils (Aerts and Chapin, 2000). Moreover, they are considered nutrient limited, particularly in nitrogen (Kristensen and Henriksen, 1998). In general, nutrient supplies have often been shown important for the growth, structure and distribution of shrubby communities (McMaster et al., 1982; Sardans et al., 2006). Specifically, in Mediterranean ecosystems nitrogen is one of the main limiting factors modulating plant growth and ecosystem functioning (Villar-Salvadoret et al., 2004; Fernandez et al., 2006).

To an extent it is difficult to predict the effects of rising temperature on soil processes. In this respect Rustad et al., (2001) suggest that winter warming in shrubland ecosystem, when there is plenty of water, may influence soil dynamics. However, they insist, it is not clear which processes will be most affected by changing thermal regime. Especially in the fine grained (temporally and spatially) Mediterranean mosaics this task is even more difficult. Uncertainty is enhanced because most warming studies conducted in the past referred to mean temperature values. However, it appears reasonable to hypothesize that apart from average, Max and/or Min temperatures exert disproportional effects on soil processes. Accordingly it is interesting to investigate whether changes in soil processes induced by altered thermal regimes are mostly modulated by the upper and/or lower limits of temperature and which further effect these temperature correlates may exert on soil variables.

Within this rather uncertain framework the aim of this study was to investigate how soil variables, relating mainly to nitrogen dynamics, would be affected by amplified highest and lowest values of temperature induced by climate warming. Specifically, we intended to investigate how different upper and lower temperature limits are expected to affect soil biochemical variables relating to microbial biomass, microbial activity and nitrogen cycle

\section{Study Area}

The experimental area was confined within a slope of mountain Hortiatis, about $20 \mathrm{~km}$ northeast to Thessaloniki, at an elevation of about $400 \mathrm{~m}$. The climate can be characterized Mediterranean, with a mean annual rainfall of $387.7 \mathrm{~mm}$ and mean monthly temperature in the range $4.9-31.6{ }^{\circ} \mathrm{C}$ (Hellenic National Meteorological Service). Rainfall peaks in late autumn-winter. Coldest month is January and hottest July. The upper $35 \mathrm{~cm}$ of soil consists of slightly gravelly, silty clayloam that gradually changes to stony and bouldery silty clay loam up to $50 \mathrm{~cm}$ depth.

The vegetation of the study area is dominated by Quercus coccifera (L.) shrubs, while clumps of Juniperus oxycedrus (L.) are sparsely distributed. This area has been grazed for at least the last four decades and the continuous grazing resulted in the formation of a fine grained mosaic of patches consisted of shrubs at different height (Papatheodorou et al., 1998).

\section{Experimental design and sampling}

The experimental area was a rather homogeneous flat area $(150 \times 50 \mathrm{~m}) .3$ experimental treatments were established following a randomized complete design involving three genuine replicate plots in each treatment ( $2 \times 2 \mathrm{~m}$ each). For temperature manipulation the experimental plots were covered by transparent, waterproof plastic boxes $(40 \mathrm{~cm}$ high) with different number of holes on their sides, allowing air exchange.

The original idea was to create 3 different temperature levels with temperature following the gradation: boxes with just one hole (T1) $\rightarrow$ boxes with small number of holes (T2) $\rightarrow$ boxes with large number of holes (T3). The plots were irrigated weekly with water equal to the corresponding mean precipitation rate. In all cases the litter layer was removed before the beginning of the experiment.

The experiment lasted from September 1998 to February 1999. The plastic boxes were placed in September and samples were taken during the autumn-winter period from October 1998 until February 1999, but in this paper we report overall results. To face intra plot variability, from each plot three soil samples were collected from the upper $12 \mathrm{~cm}$ of the soil and they were homogenized in 
one. The diameter of each core was $8.5 \mathrm{~cm}$. Soil samples were transported to the laboratory after sampling and stored at $4{ }^{\circ} \mathrm{C}$ until analysis.

\section{Biochemical analyses}

Within a week after sampling, fresh soil samples were sieved (mesh size $2 \mathrm{~mm}$ ) and then they were stored at $10{ }^{\circ} \mathrm{C}$ for 7 days to overcome effects resulted from the disturbance. Water holding capacity is measured by using pressure membrane extractors (Peters, 1965). Soil microbial biomass C (MBC) was measured by the fumigation-incubation method of Jenkinson and Powlson (1976), as modified by Ross (1990) in samples adjusted to $60 \%$ of their WHC. The Kc factor equals 0.45 (Jenkinson and Powlson, 1976). Soil microbial biomass N (MBN) was determined by the fumigationextraction method using a factor of 0.54 to convert $\mathrm{N}$-flush to microbial biomass $\mathrm{N}$ (Brookes et al., 1985). Soil organic $\mathrm{N}$ was measured by the Kjeldahl method (Bremmer, 1960). $\mathrm{NH}_{4}^{+}$and $\mathrm{NO}_{3}{ }^{-}$were determined in $2 \mathrm{M} \mathrm{KCl}$ extracts (1:10 soil dry weight solution), by distillation and subsequent titration (Allen, 1974). For assessing soil microbial activity, fresh soil samples were incubated at $10{ }^{\circ} \mathrm{C}$ for 5 days. The $\mathrm{CO}_{2}$ produced was determined by titration.

\section{Statistical analyses}

One-way analysis of variance (ANOVA) followed by a Bonferonni post-hoc test was performed to decide whether significant differences existed among the temperature correlates (Max, Mean, Min temperatures) in the different experimental plots. In order to examine the relationship among soil biochemical variables and the impact of temperature on these variables, regression analyses were performed on data from each treatment. Simple linear regression served two specific purposes including the identification of trends between explanatory and response variables, and the evaluation of the strength $\left(R^{2}\right)$ and significance $(P$-value) of the correlation between explanatory and response variables. A generalized linear models (GLM) Analysis of Covariance (ANCOVA) was performed to further seek for statistical differences among slopes of the linear regression lines. Finally, integrating information produced by this study, additional information provided by bibliographic survey, personal expertise and a priori knowledge on ecosystem function, a path diagram was drawn to check for statistical significance of a network of hypothesized causal links among variables.

\section{RESULTS}

The implemented experimental set-up succeeded in increasing the mean temperature of the experimental treatments to levels close to those predicted by the climate change models. More specifically, in comparison with the monthly ambient temperature $\left(T_{\text {amb }}\right)$, in the three experimental treatments we recorded an increase in mean monthly temperature of $2.1,4.9$ and $7.4{ }^{\circ} \mathrm{C}$ respectively (Figure 1). However, a more detailed analysis of data showed that among the three temperature attributes, i.e. Mean, Max and Min temperatures, only $T_{\text {mean }}$ and $T_{\max }$ values differed significantly among the three experimental treatments (Figure 2). In all sampling periods, the $\mathrm{T} 3_{\max }$ was $9-13^{\circ} \mathrm{C}$ higher than $\mathrm{T} 1_{\max }$. Moreover, in comparison with the ambient air conditions in all sampling sites $\mathrm{T}_{\max }$ displayed higher values and in some cases the $\mathrm{T} 3_{\max }$ was found to be even $16{ }^{\circ} \mathrm{C}$ higher. Therefore, it was concluded that all further analyses should be focused on the impacts of $T_{\max }$ on the soil biochemical variables.

In Table 1 are given average values for soil biochemical variables recorded at the three temperature levels. To describe the relationship of these variables to $T_{\max }$ values at all three treatments, regression lines were fitted to data (Figure 3). As shown in Table 2 in most cases the slopes of the fitted lines are highly significant. With increasing $\mathrm{T}_{1}$ max and $\mathrm{T} 2$ max the soil concentration in both $\mathrm{NO}_{3}{ }^{-}$ and $\mathrm{NH}_{4}^{+}$is reduced, whereas at the treatment $\mathrm{T3}$ it remained more or less constant notwithstanding increased $\mathrm{T} 3_{\max }$. For the rest variables the pattern is different. Organic $\mathrm{N}$ was found to be the only variable, the values of which remained independent from changing $T_{\max }$ at any treatment. In all the rest cases (microbial activity, MBN and MBC; T3 MBN values are an exception) the values increased with increased Max temperatures. 


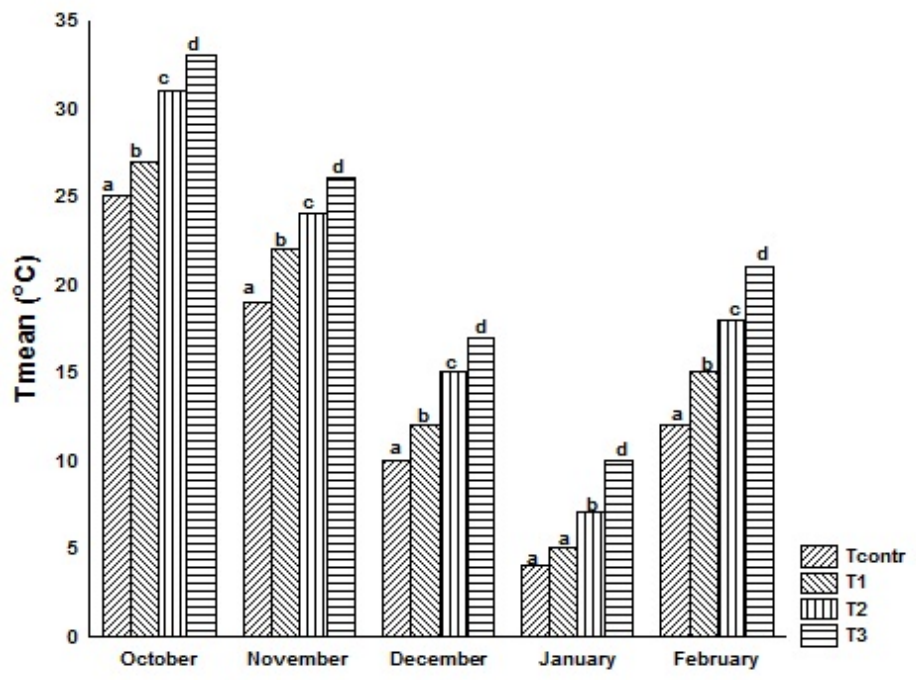

Figure 1. Mean monthly temperatures recorded in the soil of the experimental plots. T1-3: temperature recordings in the three different experimental treatments, $T_{\text {contr: }}$ temperature recorded in the control plot

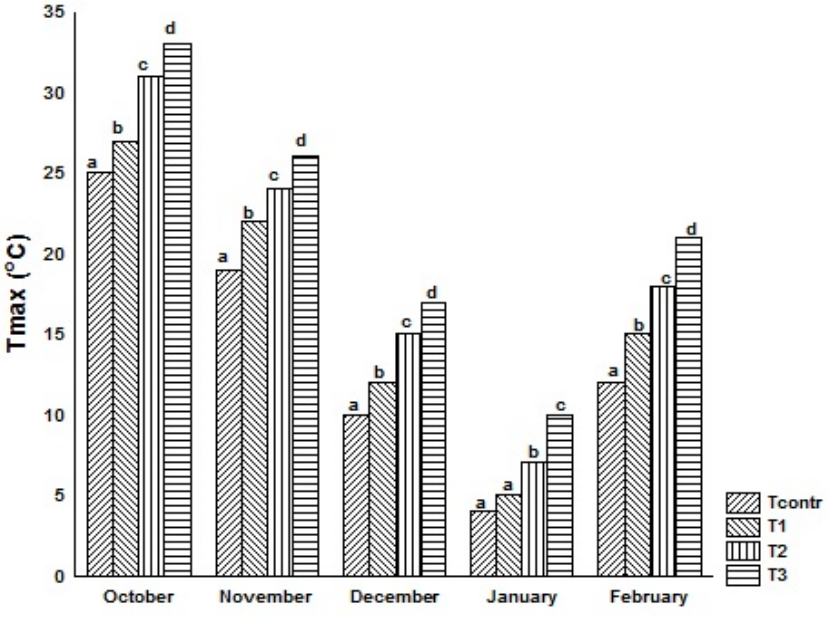

Figure 2. Mean monthly maximum temperatures recorded in the soil of the experimental plots. T1-3: max temperatures recorded in the three different experimental treatments, $\mathrm{T}_{\text {contr }}$ : maximum temperature recorded in the control plot

Table 1. Mean values $( \pm \mathrm{SE})$ of the soil biochemical variables recorded in the three experimental treatments T1-3

\begin{tabular}{l|ccc}
\hline & T1 & T2 & T3 \\
\hline MBC ( $\mathrm{mg} \mathrm{g}^{-1}$ d.w.) & $1.930 \pm 0.270$ & $1.970 \pm 0.170$ & $2.215 \pm 0.271$ \\
MBN (mg g ${ }^{-1}$ d.w.) & $0.365 \pm 0.044$ & $0.203 \pm 0.027$ & $0.124 \pm 0.021$ \\
Microbial activity $\left(\mu \mathrm{CO}_{2} \mathrm{~g}^{-1} \mathrm{~h}^{-1}\right)$ & $0.476 \pm 0.059$ & $0.305 \pm 0.051$ & $0.253 \pm 0.052$ \\
Organic N (mg g ${ }^{-1}$ d.w.) & $4.395 \pm 0.323$ & $3.955 \pm 0.231$ & $3.055 \pm 0.168$ \\
$\mathrm{NH}_{4}^{+}\left(\mu \mathrm{g} \mathrm{g}^{-1}\right.$ d.w.) & $57.500 \pm 12.047$ & $64.300 \pm 14.256$ & $47.420 \pm 8.103$ \\
$\mathrm{NO}_{3}^{-}\left(\mu \mathrm{g} \mathrm{g}^{-1}\right.$ d.w.) & $64.700 \pm 13.199$ & $69.400 \pm 14.485$ & $52.710 \pm 8.219$ \\
\hline
\end{tabular}

Table 2. Results of simple regression analysis.

Soil biochemical variables were the dependent and $\mathrm{T}_{\max }$ was the independent variable (symbols as in Table $1,{ }^{*}<0.05,{ }^{*}<0.01,{ }^{* * *}<0.001$, ns: not significant)

\begin{tabular}{|c|c|c|c|c|c|c|c|c|c|}
\hline & \multicolumn{3}{|c|}{$T 1$} & \multicolumn{3}{|c|}{$T 2$} & \multicolumn{3}{|c|}{ T3 } \\
\hline & $\mathbf{R}^{2}$ & $b_{0}$ & $p$-value & $\mathbf{R}^{2}$ & $b_{0}$ & $p$-value & $\mathbf{R}^{2}$ & $\mathbf{b}_{0}$ & p-value \\
\hline MBC & 0.77 & 0.0648 & $\star \star \star ~$ & 0.74 & 0.0647 & 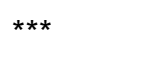 & 0.63 & 0.0624 & $\star \star$ \\
\hline MBN & 0.62 & 0.0093 & * & 0.59 & 0.0092 & ** & 0.10 & 0.0002 & ns \\
\hline Microbial activity & 0.68 & 0.0131 & ** & 0.59 & 0.0118 & $\star \star$ & 0.56 & 0.0108 & ** \\
\hline Organic N & 0.14 & 0.0487 & ns & 0.16 & 0.0461 & ns & 0.19 & -0.0341 & ns \\
\hline $\mathrm{NH}_{4}^{+}$ & 0.58 & -0.0027 & $* *$ & 0.61 & -0.0036 & $* *$ & 0.11 & -0.0008 & ns \\
\hline $\mathrm{NO}_{3}^{-}$ & 0.55 & -0.0029 & $\star *$ & 0.59 & -0.0036 & $\star *$ & 0.16 & -0.0009 & ns \\
\hline
\end{tabular}



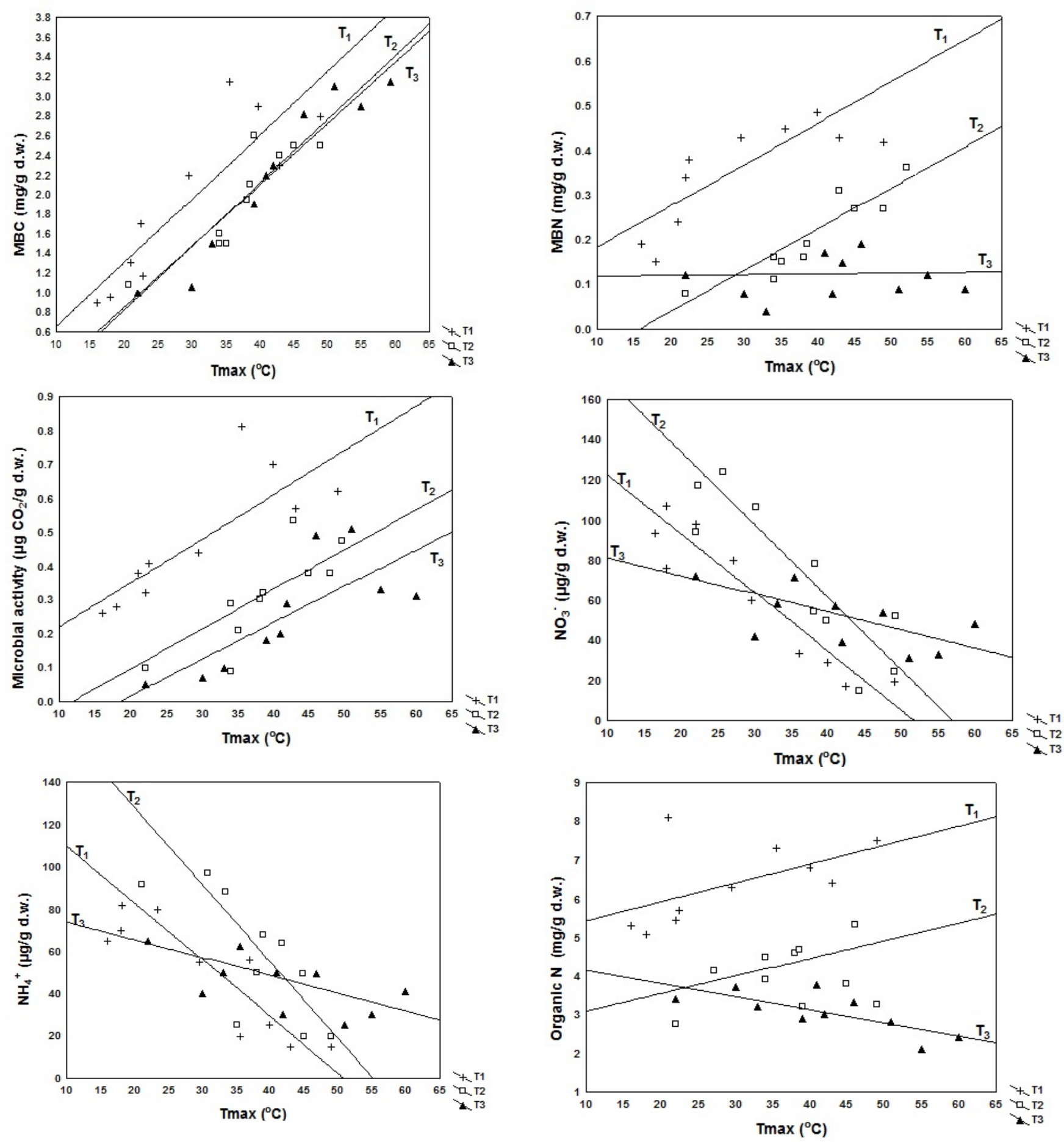

Figure 3. Simple regression model describing the dependence of soil biochemical variables on $\mathrm{T}_{\max }$ in the three experimental treatments (symbols as in Table 1)

To test whether the slopes of the fitted lines differ at the three treatments a further analysis of covariance (ANCOVA test for equality of slopes) was performed and the results are given in Table 3. In almost all cases the fitted lines at T1 and T2 are parallel, whereas their slopes differ significantly from those fitted at T3. An exception to this pattern is exhibited by $\mathrm{NO}_{3}{ }^{-}$and $\mathrm{NH}_{4}{ }^{+}$concentrations where the slope of the fitted lines was found significantly higher at the T2 treatment. 
Table 3. The slopes $b$ of the simple regression lines depicted in Figure 3 and the results of ANCOVA applied to test for statistical differences among them. Different letters correspond to statistically significant differences

\begin{tabular}{l|ccc}
\hline & $T_{1}$ & $T_{2}$ & $T_{3}$ \\
\hline MBC & $0.0648^{a}$ & $0.0647^{a}$ & $0.0624^{b}$ \\
MBN & $0.0093^{a}$ & $0.0092^{a}$ & $0.0002^{b}$ \\
Microbial activity & $0.0131^{a}$ & $0.0118^{a}$ & $0.0108^{b}$ \\
Organic N & $0.0487^{a}$ & $0.0461^{a}$ & $-0.0341^{a}$ \\
$\mathrm{NH}_{4}{ }^{+}$ & $-0.0027^{b}$ & $-0.0036^{a}$ & $-0.0008^{c}$ \\
$\mathrm{NO}_{3}{ }^{-}$ & $-0.0029^{\mathrm{b}}$ & $-0.0036^{\mathrm{a}}$ & $-0.0009^{\mathrm{c}}$ \\
\hline
\end{tabular}

To model above information a structural equation model was developed (Figure 4). While model building, additional information from bibliography as well as theoretical considerations are also taken into account. The significance of the model fitting against experimental data was evaluated employing Se-Path analysis. Several model versions were applied to data and the selection of the most applicable was based upon the Akaike Information Criterion (AIC). Relevant results showing acceptable goodness of fit are depicted in Table 4. As shown, the $X^{2}$ value indicates highly significant fitting, while the Population Gamma none centrality index reaches values close to 0.9 which show acceptable model parsimony. As depicted, the only soil parameter directly affected by $\mathrm{T}_{\max }$ is MBC. Then, microbial biomass is expected to exert a further effect on almost all other parameters (microbial activity, $\mathrm{NH}_{4}{ }^{+}$and $\mathrm{NO}_{3}{ }^{-}$). Thus $\mathrm{T}_{\max }$ is showed to have indirect effects on the majority of the soil variables. Organic $\mathrm{N}$ affected mainly the concentrations of $\mathrm{MBN}$ and $\mathrm{NO}_{3}{ }^{-}$, whereas this latter is modulated by the concentration in $\mathrm{NH}_{4}{ }^{+}$.

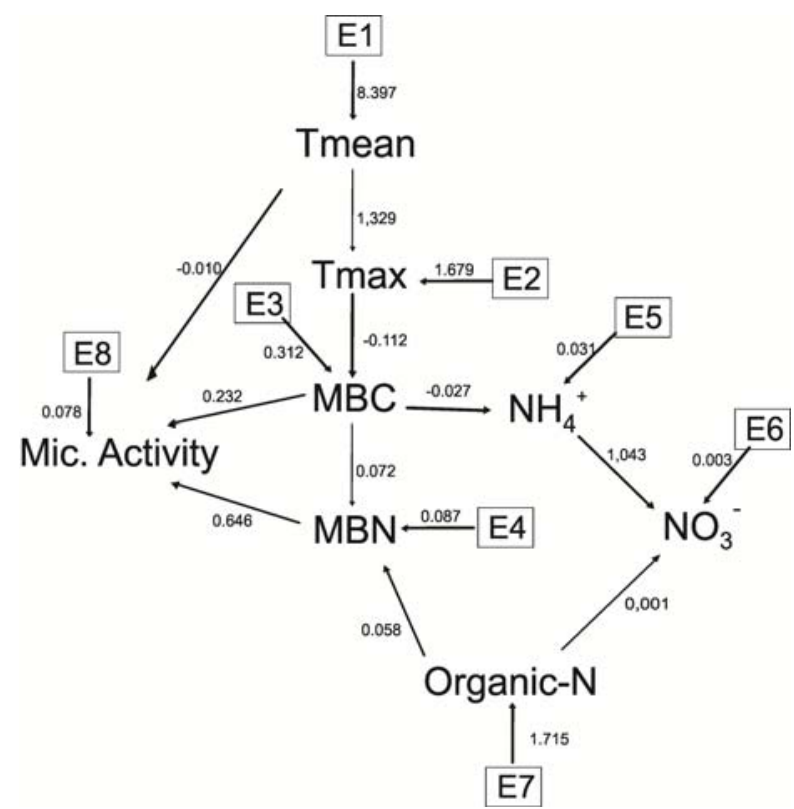

Figure 4. The structural model fitted on data. Symbols (as in Table 1) represent manifest variables, whereas labelled boxes represent latent variables. Numbers on arrows correspond to regression coefficients 
Table 4. $\mathrm{X}^{2}$ for goodness of fit, Non-centrality Population Gamma index for model parsimony and Akaike Information Criterion estimated for the structural model fitted on data

\begin{tabular}{l|lll}
\hline$X^{2}=61.354, D F=17, p$-level $=0.000$ & & \\
\hline Population Gamma & Lower 90\% & Value & Upper 90\% \\
& 0.705 & 0.820 & 0.921 \\
Akaike Information Criterion & & 3.426 & \\
\hline
\end{tabular}

\section{DISCUSSION}

Climate change due to greenhouse gas emissions is predicted to raise the mean global temperature by $1.4-5.8{ }^{\circ} \mathrm{C}$ over the next century (Houghton et al., 2001) and this increase is most likely to touch more the highest and to a lesser extent the lowest levels of temperature. In the present study, the implemented experimental set-up succeeded in increasing the mean temperature in the experimental treatments creating temperature gradients close to those predicted by the climate change models. However, among temperature upper and lower limits only $\mathrm{T}_{\max }$ levels were significantly affected and it justifies our decision to delimit the discussion on their impacts.

Concerning the values of the studied parameters, the amounts of organic N, MBC, MBN, microbial activity and inorganic nitrogen recorded in all three treatments were comparable with values recorded in the soil of other Mediterranean grasslands in Northern Greece (Monokrousos et al., 2004; Papatheodorou et al., 2004). Further, the results of this paper showed that an average increase in soil $\mathrm{T}_{\max }$ in the range from 5 to $8{ }^{\circ} \mathrm{C}$ (treatments $\mathrm{T} 1$ and T2) resulted to an increase in the values of all variables referring to the biomass and activity of the soil microbial community (MBC, MBN, microbial ctivity), the values of organic $\mathrm{N}$, as well as to a decrease in the concentration of $\mathrm{NO}_{3}$ and $\mathrm{NH}_{4}{ }^{+}$. By contrast an average increase of $13^{\circ} \mathrm{C}$ in $\mathrm{T}_{\max }$ (treatment T3) exerted mixed effects.

It is well documented (Esteban-Parra et al., 1998; Pinol et al., 1998) that in Mediterranean areas, high summer temperatures along with low or absent precipitation generate a deep water stress. However, the stress factor in winter is the low level of temperature. Accordingly, moderate increase in soil temperature can enhance the microbial biomass and activity from autumn to spring when the soil water content is easily available (Sardans et al., 2008). More precisely, the results of the current study indicate that an increase of $\mathrm{T}_{\max }$ by about $5{ }^{\circ} \mathrm{C}$ would have strong positive impact on the microbial biomass, whereas further increases would also influence positively the rate of microbial growth, though not equally strongly. It is worth noticing that similar results are reported in other studies contacted in Mediterranean ecosystems but focusing on temperature means. Actually, these results showed that an average increase of about $2-3^{\circ} \mathrm{C}$ would have rather strong positive effects on soil microbial biomass and activity (Andersen et al., 2010). It seems that converging findings concerning either $\mathrm{T}_{\max }$ or $\mathrm{T}_{\text {mean }}$ allow hypothesizing that even slight increase in the winter temperature in the near future would result in considerable step-up of the microbial biomass in Mediterranean soils.

To analogous conclusions lead also results showing increasing microbial activity with increasing $T_{\max }$ especially in T1 treatments. The increase in soil respiration in response to warming is consistent with results from in situ studies, which have repeatedly demonstrated significant positive relationships between temperature and soil respiration (Schlenter and Van Cleve, 1985; Pinol et al., 1995). Moreover, a meta-analysis of 12 warming experiments indicated that average warming of $3{ }^{\circ} \mathrm{C}$ increased soil respiration by $20 \%$ (Rustad et al., 2001). In conjunction with the fact that an increase in microbial biomass is possible to enhance also microbial activity in soils, above results allows concluding that at least in the short term a moderate increase of temperature could be beneficial for both soil microbial populations and their activity.

In the previous paragraphs we argue that the effects of changing $T_{\max }$ on microbial biomass and activity are to a large extent comparable with those referring to $T_{\text {mean }}$ impacts. However it is not the case with nitrification processes. Indeed, based upon average values, many researchers (Ryan et al., 1998; Wang et al., 2006) have pointed out that in temperate ecosystems increasing temperature is positively correlated with nitrification. Consequently, the received suggestion is that increases in temperature may favour oxidation capacity, which has also been shown to relate with soil nitrification process (Brzezinska et al., 1998). Moreover, it is further suggested that increased rates of $\mathrm{N}$ mineralization driven by climate warming may increase plant $\mathrm{N}$ availability, which, coupled with an 
extended growing season, could stimulate plant growth in N-limited systems, provided water is not limiting (Sierra, 1997; De Valpine and Harte, 2001). In contrast to aforementioned suggestions in our Mediterranean soils we found that the inorganic forms of nitrogen reduced with increased $T_{\max }$. Taking into consideration that increasing MBN with increased $T_{\max }$ indicates accumulation of nitrogen ultimately serving microbial growth needs, we suggest that regarding $N$ processes in our Mediterranean soil the response to $T_{\max }$ is a delicate balance between microbial immobilization and mineralization. Actually, apart from enhanced oxidation capacity and mineralization rate, increased $\mathrm{T}_{\max }$ favours increases in belowground carbon allocation and consequently enhanced microbial nitrogen immobilization and reduced net $\mathrm{N}$ mineralization (Wan, 2005).

Noticeable is also that changing $T_{\max }$ in the different experimental treatments exerts disproportional effects on the composition of the soil microbial community. In the less warm T1 and T2 treatments the amount of accumulated nitrogen in microbial biomass increases significantly with increasing $\mathrm{T}_{\max }$, and the same occurred also with $\mathrm{MBC}$, in all probability resulted from the increasing of both bacterial and fungal biomass. By contrast in the warmer T3 treatments increasing MBC with increased $T_{\max }$ is not accompanied by increasing MBN. Taking into account that the $\mathrm{N}$ content of fungi is considerably lower than that of bacteria (Alexander, 1977), it is plausible that in the warmer plots fungal biomass dominates over its bacterial counterpart. Above statement is reinforced by suggestions that over a certain threshold warming may enhance fungal contribution to the microbial community (Luo et al. 2001), because stressful conditions such as elevated soil temperature are likely to facilitate fungi to survive better, since they rely on more aerobic conditions (Santruckova et al., 2003), and further that, due to their filamentous nature, they are more tolerant to higher soil temperature and drying (Holland and Coleman, 1987). Overall, the data suggest that the increases in $T_{\max }$ are expected to have a positive effect on the soil microbial community in our Mediterranean shrubland, which consequently will affect many other soil variables. Specifically, a small increase in the $T_{\max }$ levels would favour the dominance of bacterial populations, while larger increases might be in favour of fungal population.

Se-Path analysis revealed that $M B C$ is the only variable affected directly by changing $T_{\max }$ and this remark is in agreement with Gorissen et al., (2004) suggesting that in shrubland ecosystems soil microbial biomass is an early indicator of changes in soil dynamics induced by increasing temperature. Morover, Panikov, (1999) considers microbial communities as the more reactive component of a terrestrial ecosystem to external stress due to their potential for rapid growth and turnover.

Moreover, the significant fitting of our structural model to experimental data add support to suggestions that temperature is an important environmental factor modulating the activity and determining the abundance and the composition of the soil microbial community (Pettersson and Bååth, 2003). The model shows further that modulated by changing $T_{\max }$ values the microbial biomass, - represented in our study as MBC and MBN - has central role in the soil dynamics, affecting many other variables and is of crucial importance for $\mathrm{N}$ cycling. Then, increased temperatures, - especially its $\mathrm{T}_{\max }$ correlate - during autumn-winter would potentially create a positive combination of abiotic factors for further increases in the microbial populations since even small increases in $T_{\max }$ could be proved sufficient to enhance microbial biomass (Sowerby et al., 2005) and indirectly available $\mathrm{N}$ during autumn-winter.

\section{CONCLUSIONS}

Overall, our data suggests that in our Mediterranean shrubland the increase of $T_{\max }$ induced by climate change is expected to have a direct effect only on the soil microbial biomass (MBC) and to exert an indirect effect on the majority of the other soil variables. An increase of the $T_{\max }$ levels could also have an important and significant impact on the activity and structure of the microbial community. Moreover, a small increase of the $T_{\max }$ levels induced by climate change could favour the dominance of the bacterial soil populations, while a larger increase could result favour increases in the fungal populations.

\section{REFERENCES}

Aerts R. and Chapin F.S. (2000), The mineral nutrition of wild plants revisited: A re-evaluation of processes and patterns, Advances in Ecological Research, 30, 1-67. 
Alexander M. (1977), Introduction to Soil Microbiology, $2^{\text {nd }}$ ed. Wiley, New York.

Allen S.E. (1974), Chemical Analysis of Ecological Materials, Blackwell Scientific Publications.

Andresen LC., Michelsen A., Ambus P. and Beier C. (2010), Belowground heathlandresponses after 2 years of combined warming, elevated $\mathrm{CO}_{2}$ and summer drought, Biogeochemistry, 101, 27-42

Bremmer J.M. (1960), Determination of nitrogen in soil by Kjedahl method, Journal of Agricultural Science, 55, 1-23.

Brookes P.C., Landman A., Pruden G. and Jenkinson D.S. (1985), Chloroform fumigation and the release of soil nitrogen: a rapid direct extraction method to measure microbial biomass nitrogen in soil, Soil Biology and Biochemistry, 17, 837-842.

Brzezinska, M., Stepniewska, Z. and Stepniewski, W. (1998), Soil oxygen status and dehydrogenase activity, Soil Biology and Biochemistry, 30, 1783-1790.

De Valpine P. and Harte J. (2001), Plant responses to experimental warming in a montane meadow, Ecology, 82, 637-648.

Dimitrakopoulos P.G., Galanidis A., Siamantziouras A.S.D., Troumbis A.Y. (2005), Short-term invasibility patterns in burnt and unburnt experimental Mediterranean grassland communities of varying diversities, Oecogia, 143, 428-437.

Esteban-Parra M.J., Rodrigo F.S. and Castro-Diez Y. (1998), Spatial and temporal patterns ofprecipitation in Spain for the period 1880-1992, International Journal of Climatology, 18, 15571574.

Fernandez M., Novillo C. and Pardos J.A. (2006), Effects of water and nutrient availability in Pinus pinaster ait. Open pollinated families at an early age: growth, gas exchange and water relations, New Forest, 31, 321-342.

Fyllas N.M. and Troumbis A.Y. (2009), Simulating vegetation shifts in north-eastern Mediterranean mountain forests under climatic change scenarios, Global Ecology and Biogeography, 18, 64-77.

Gorissen A., Tietema A., Joosten N.N., Estiarte M., Penuelas J., Sowerby A., Emmett B.A. and Beier C. (2004), Climate change affects carbon allocation to the soil in shrublands, Ecosystems, 7, 650-661.

Holland E.A., Coleman D.C. (1987), Litter placement effects on microbial and organic- matter dynamics in an agroecosystem, Ecology, 68, 425-433.

Houghton J.T., Ding Y., Griggs D.J., Noguer M., van der Lindern P.J. and Xiaosu, D. (Eds.), (2001), Climate Change 2001: The Scientific Basis, Cambridge University Press, New York, pp 881.

Intergovernmental Panel on Climate Change (IPCC) (1996), Climate change 1995: the science of climate change, Houghton JT, Meira Filho LG, Callander BA, Harris N,Kattenberg A, Maskell K (eds). Cambridge University Press, Cambridge.

Jenkinson D.S. and Powlson D.S. (1976), The effects of biocidal treatments on metabolism in soil, Soil Biology and Biochemistry, 8, 209-213.

Kristensen H.L. and Henriksen K. (1998), Soil nitrogen transformations along a successional gradient from Calluna heathland to Quercus forest at intermediate atmospheric nitrogen deposition, Applied Soil Ecology, 8, 95-109.

Kutiel H.M. and Maheras P. (1998), Variations in the temperature regime across the Mediterranean during the last century and their relationship with circulation indices, Theoretical and Applied Climatology, 61, 39-53.

Luo Y., Wan S., Hui D. and Wallace L.L. (2001), Acclimation of soil respiration to warming in a tall grass prairie, Nature, 413, 622-625.

McMaster G.S., Jow W.M. and Kummerow J. (1982), Response of Adenostoma fasciculatum and Ceanothus gregii chaparral to nutrient additions, Journal of Ecology, 70, 745-756.

Monokrousos N., Papatheodorou E.M., Diamantopoulos J.D. and Stamou G.P. (2004), Temporal and spatial variability of soil chemical and biological variables in a Mediterranean shrubland, Forest Ecology and Management, 202, 83-91.

Sardans J., Penuelas J. and Estiarte M. (2008), Changes in soil enzymes related to C and N cycle and in soil $\mathrm{C}$ and $\mathrm{N}$ content under prolonged warming and drought in a Mediterranean shrubland, Applied Soil Ecology, 39, 223-235.

Panikov N.S. (1999), Understanding and prediction of soil microbial community dynamics under global change, Applied Soil Ecology, 11, 161-176.

Papatheodorou E.M., Pantis J.D., Stamou G.P. (1998), The effect of grazing on phenology and biomass allocation in Quercus coccifera (L.), Acta Oecologica-international Journal of Ecology, 19, 339-347.

Papatheodorou E.M., Stamou G.P. and Giannotaki A. (2004), A Response of soil chemical and biological variables to small and large scale changes in climatic factors, Pedobiologia, 48, 329-338. 
Penuelas J. and Boada M. (2003), A global change-induced biome shift in the Montseny mountains (NE Spain), Global Change Biology, 9, 131-140.

Penuelas J., Filella I., Sabate S. and Gracia C. (2005), Natural systems: terrestrial ecosystems, In: Report on Climate Change in Catalonia, Llebot, J.E. (Ed.),. Institut d'Estudis Catalans, Barcelona, pp. 517553.

Peters D.B. (1965), Water availability, In: Methods of Soil Analysis, Black C.A. (Ed.), Am. Soc. Agron. Inc., Madison, WI, pp. 279-285.

Pettersson M. and Baath E. (2003), Temperature-dependent changes in the soil bacterial community in limed and unlimed soil, FEMS Microbiology Ecology, 45, 13-21.

Pinol J., Alcaniz J.P. and Roda F. (1995), Carbon dioxide efflux and $\mathrm{PCO}_{2}$ in soils of three Quercus ilex montane forests, Biogeochemistry, 30, 191-215.

Ross D.J. (1990), Measurements of microbial biomass $C$ and $N$ in grassland soils by fumigationincubation procedures: influence of inoculum size and the control, Soil Biology and Biochemistry, 3, 289-294.

Rustad L.E., Campbell J.L., Marion G.M., Norby R.J., Mitchell M.J., HartleyA.E.,Cornelissen J.H.C. and Gurevitch J. (2001), A meta-analysis of the response of soil respiration, net nitrogen mineralization, and aboveground plant growth to experimental ecosystem warming, Oecologia, 126, 543-562.

Ryan M.G., O'Toole P. and Farrell E.P. (1998), The influence of drought and natural rewetting on nitrogen dynamics in a coniferous ecosystem in Ireland, Environmental Pollution, 102, 445-451.

Santruckova H., Bird M.I., Kalaschnikov Y.N., Grund M., Elhottova D., Simek M., Grigoryev S., Gleixner G., Arneth A., Schulze E.D. and Lloyd J. (2003), Microbial characteristics of soils on a latitudinal transect in Siberia, Global Change Biology, 9, 1106-1117.

Sardans J., Roda F. and Penuelas J. (2006), Effects of a nutrient pulse supply on nutrient status of the Mediterranean trees Quercus ilex subsp. ballota and Pinus halepensis on different soils and under different competitive pressure, Trees, 20, 619-632.

Schlenter R.E. and Van Cleve K. (1985), Relationship between CO2 evolution from soil, substrate temperature, and substrate moisture in four mature forest types in interior Alaska, Canadian Journal of Forest Science, 15, 97-106.

Shaver G.R., Canadell J., Chapin F.S. III, Gurevitch J., Harte J., Henry G., Ineson I., Jonasson S., Melillo J., Pitelka L. and Rustad L. (2000), Global warming and terrestrial ecosystems: a conceptual framework for analysis, BioScience, 50, 871-882.

Shaw M.R., Zavaleta E.S., Chiariello N.R., Cleland E.E., Mooney H.A., Field C.B. (2002), Grassland responses to global environmental changes suppressed by elevated $\mathrm{CO}_{2}$, Science, 298, 1987-1990.

Sierra J. (1997), Temperature and soil moisture dependence of $\mathrm{N}$ mineralization in intact soil cores, Soil Biology \& Biochemistry, 29, 1557-1563.

Sowerby A., Emmett B., Beier C., Tietema A., Penuelas J., Estiarte M., Van MeeterenM.J.M., Hughes S., Freeman C. (2005), Microbial community changes in heathland soil communities along a geographical gradient: interaction with climate change manipulations, Soil Biology and Biochemistry, 37, 1805-1813.

Villar-Salvador P., Planelles R., Enrıquez E. and Rubira J.P. (2004), Nursery cultivation regimes, plant functional attributes, and field performance relationships in the Mediterranean oak Quercus ilex L., Forest Ecology and Management, 196, 257-266.

Wan S.Q., Hui D.F., Wallace L. and Luo Y.Q. (2005), Direct and indirect effects ofexperimental warming on ecosystem carbon processes in a tallgrass prairie, Global Biogeochemical Cycles, 19, GB2014.

Wang C., Wan S., Xing X., Zhang L. and Han X. (2006), Temperature and soil moisture interactively affected soil net $\mathrm{N}$ mineralization in temperate grassland in Northern China, Soil Biology and Biochemistry, 38, 1101-1110. 